\title{
PRODUCTIVE PERFORMANCE, PHYSIOLOGICAL AND ANTIOXIDANT STATUS OF GROWING V-LINE RABBITS DRINKING WATER SUPPLEMENTED WITH AMPHORA COFFEAEFORMIS DIATOMS ALGA EXTRACT DURING HOT CONDITIONS.
}

\author{
I.H. Salim ${ }^{1}$, M. Abdel-Aal ${ }^{2}$, Doaa O. Awad ${ }^{3}$. and A.B. El-Sayed ${ }^{4}$ \\ 1 Poultry Nutrition Dept., Animal Production Institute, Dokki, Cairo, Egypt \\ ${ }^{2}$ Animal Production Dept., Faculty of Agriculture, Cairo University, Giza, Egypt \\ ${ }^{3}$ Central Laboratory for Agricultural Climate, Dokki, Cairo, Egypt \\ ${ }^{4}$ Algal Biotech. unit, Fertilization Technology Dept., National Research Centre, Dokki, Cairo, Egypt
}

(Received 18/6/2019, accepted 29/7/2019)

\section{SUMMARY}

\begin{abstract}
total number of 60 weaned male and female V-line rabbits were used to evaluate supplemented Amphora coffeaeformis (A. coffeaeformis) alga extract (ACE) in drinking water on productive performance, carcass traits, physiological and antioxidant status during hot conditions. The experimental rabbits were randomize divided into four equal groups $(\mathrm{n}=15$ each). In the first group (C), rabbits were kept as control (drank water without additives), in the $2^{\text {nd }}$ group rabbits drank water supplemented with vitamins and minerals $(1 \mathrm{ml} / \mathrm{liter}, \mathrm{T} 1)$, in the $3^{\text {rd }}$ group rabbits drank water supplemented with $0.5 \mathrm{ml}$ ACE $\left(0.5 \mathrm{ml} / 1\right.$ iter, T2) while in the $4^{\text {th }}$ group rabbits drank water supplemented with $1 \mathrm{ml}$ ACE (1 $\mathrm{ml} /$ liter, T3). Body weight and total feed intake were weekly recorded. Total body gain, feed conversion were calculated and carcass traits of rabbits were also measured. Blood hematological, metabolites and antioxidant biomarkers were determined. The results showed that no significant differences were observed among groups in concern final body weight or body weight gain, carcass or internal organs weight percentages, blood hematological parameters and indices. While, 0.5 and $1 \mathrm{ml} \mathrm{ACE} \mathrm{recorded} \mathrm{significantly} \mathrm{the} \mathrm{best} \mathrm{antioxidation}$ indices (MDA and Catalase). Supplementation of rabbit drinking water with A. coffeaeformis alga had positive impact on performance and antioxidant capacity of growing rabbits under heat stress condition.
\end{abstract}

Keywords: rabbits, algae, diatoms, growth, antioxidant, blood metabolites and heat stress

\section{INTRODUCTION}

Exposure of animals to heat stress stimulates a sequence of drastic changes regarding biological functions. It is include a decrease in feed efficiency, utilization, disturbances in water, change in protein, energy and mineral balances, enzymatic activities, hormonal secretions and blood metabolites. This ending by impairment both productive and reproductive performance. Heat stress also, altering natural immunity and making animals more vulnerable to disease (Habeeb et al., 2008 and 2018).

Rabbits are highly sensitive to heat stress due to the absence of sweat glands or any other means of eliminating excess body heat (Marai et al., 2008 and Morera et al., 2012). Several researches claimed that such adverse impacts are mainly linked to an extreme generation of free radicals and active oxygen species with decrease in antioxidant resistance (Ganaie et al., 2013 and Nisar et al., 2013). Hence, several in vivo and in vitro trials confirmed the importance of antioxidant supplementation in ameliorating heat stress effect (Alhidary et al., 2012 and McKee and Harrison, 2013). Vitamins, essential oils, fats, and amino acids are the main dietary supplements with marked antioxidant properties. But, for the time being, the use of natural antioxidants has paid great interest from both livestock producers and nutritionists (Tawfeek et al., 2014). Thus, recently many researchers are interested in finding safe and effective natural antioxidants which can be substituted the synthetic commercial antioxidant supplements such as butylated hydroxyl anisole (BHA), butylated hydroxy tolouene (BHT), $\alpha$-tocopherol and propyl gallate (PG) that have been used in order to reduce oxidative damages (Lee et al., 2008). 


\section{Salim et al.}

Algae have attracted a great deal of interest as alternative sources of nutrients. It is logical to consider that algae could be a key resource containing rich source of functional metabolites such as polysaccharides, proteins, peptides, amino acids, lipids, polyphenols, and minerals (Brown et al 2014). Otherwise, diatoms were considered as promising source of sustainable antioxidants because they have effective radical scavengers, ability to adapt and rapidly grow either in open or closed cultivation facilities (Banerjee et al. 2011). Diatoms contribute about $40 \%$ of the marine primary production, constituting half of entire organic material produced in the planet (Rousseaux and Gregg, 2014). Interestingly, under certain conditions, diatoms produce the highest amounts of Polyunsaturated fatty acids (PUFAs) among phytoplankton groups (Leflaive and Ten-Hage, 2009). Diatoms can produce inhibitory compounds against bacteria, constituting an alternative to the use of chemicals to control pathogenic bacterial growth. Antibacterial activity has been detected in co-cultures of microalgae (Qasem et al., 2016, Molina-Cardenas and Sánchez-Saavedra, 2017, Badr et al., 2017, El-Sayed et al., 2018a and Ayoub et al., 2019). Lee et al. (2009) studied A. coffeaeformis diatom extracts for their potential antioxidant effects and they found that A. coffeaeformis exhibited lipid peroxidation inhibitory activity significantly higher than that of $\mathrm{a}$ - tocopherol. In addition, A. coffeaeformis is rich in hydrophilic and hydrophobic anti oxidative compounds with different anti-oxidative properties. Ayoub et al. (2019) indicates that the oral administration of $A$. coffeaeformis at three concentration of $(10,20$ and $30 \mathrm{~g} / \mathrm{kg}$ diet) in Nile tilapia diets leads to enhance the growth performance, feed efficiency, serum lysozyme activity and improved total protein, albumin and globulin. Khatoon et al. (2009) showed that isolated marine diatoms (Amphora, Navicula and Cymbella) grown on substrate could be used as feed supplement in enhancing the growth and survival of Penaeus monodon postlarvae. However, still there is not enough data or researches about the effects of $A$. coffeaeformis or diatoms on rabbits or poultry performance.

Therefore, the objective of this study was to evaluate the effect of A. coffeaeformis diatoms Alga extract supplementation in drinking water on growth performance, carcass, physiological and antioxidant status of growing rabbits under heat stress conditions.

\section{MATERIALS AND METHODS}

\section{Experimental design and management}

The present study was carried out in El-Semman Unit for development of Rabbit Research, Faculty of Agriculture, Cairo University. It was lasted six weeks from 18 July to August, 29 2018. A total number of 60 weaned V-line rabbits were used ( 5.5 weeks old and average body weight was $853.4 \pm 22.98 \mathrm{gm}$ ). The experimental rabbits were divided randomly into four equal groups $\left(\mathrm{n}=15\right.$ each). In $1^{\text {st }}$ group $(\mathrm{C})$, rabbits were kept as control (drank water without additives); in the $2^{\text {nd }}$ group rabbits drank water supplemented with vitamins and minerals $(1 \mathrm{ml} /$ liter, $\mathrm{T} 1)$, in the $3^{\text {rd }}$ group rabbits drank water supplemented with $0.5 \mathrm{ml}$ A. coffeaeformis alga extract $\left(0.5 \mathrm{ml}\right.$ ACE/liter, T2); while in the $4^{\text {th }}$ group rabbits drank water supplemented with $1 \mathrm{ml}$ A. coffeaeformis alga extract (1 ml ACE/liter, T3).

Rabbits are healthy and diagnosed as clinically free from internal and external parasites. Rabbits were kept under the same management and environmental conditions and housed in standard dimensions wired metallic cages $(30 \times 40 \times 25 \mathrm{~cm})(5$ rabbits/2cage) and equipped with feeding hoppers. All rabbit groups were fed and drink ad libitum. Feed ingredients and chemical composition of the concentrate pelleted experimental diet that cover the requirements of growing rabbits (according to the Agriculture Ministry Decree 1996) are shown in Table (1).

\section{Alga extracts preparation}

The locally isolate Bacillariophyta alga, Amphora coffeaeformis (El-Sayed et al., 2018b) was massively produced (Algal Biotechnology Unit, National Research Centre, Dokki, Giza, Egypt) based on F2 nutrient solution (Gillard and Ryther, 1962). Outdoor mass production was performed within semiclosed photobioreactor 1200L capacity of fully transparent Zigzag shape photobioreactor (El-Sayed et al., 2018b). Outdoor nutrient solution was made from commercial fertilizers compounds as suggested early by El-Sayed et al. (2001). Technical processes were performed as described by Hassan et al. (2015).

\section{Alga biochemical analysis}

\section{Chlorophylls and carotenoids determination}

The acetone algal extract was transferred to separating funnel containing petroleum ether following by drying with anhydrous sodium sulphate and spectrophotometrically assayed (Davies, 1976). Total 
chlorophyll, chlorophyll a and chlorophyll b were spectrophotometericaly determined at wavelengths 645 and $663 \mathrm{~nm}$ (Enwereuzoh and Onyeagoro, 2014). $\beta$-carotene was determined at $436 \mathrm{~nm}$, while total carotenoids were determined at $450 \mathrm{~nm}$ (Mustapha and Babura 2009).

Table (1): Ingredient and calculated analysis of the grower diets during 15-28 d.

\begin{tabular}{lccc}
\hline Ingredient & $\%$ & Calculated analysis & \\
\hline Alfalfa hay & 35.20 & CP \% & 17.0 \\
Yellow corn & 12.60 & CF\% & 12.6 \\
Soybean meal (44\%) & 14.50 & DE Kcal/kg & 2500 \\
Wheat bran & 14.34 & Ca \% & 1.15 \\
Barely & 17.00 & Total P \% & 0.80 \\
Molasses & 3.00 & Lys. \% & 0.93 \\
Lime stone & 1.00 & Meth. \% & 0.34 \\
Mono calcium phos. & 1.60 & Meth + Cys \% & 0.60 \\
Vit.\&Min. Premix* & 0.30 & & \\
DL-Methionin & $0 . .06$ & & \\
L-Lysine-HCl & $0 . .05$ & & \\
NaCl & 0.35 & & \\
Total & 100 & & \\
\hline
\end{tabular}

*Supplied per $\mathrm{kg}$ of diet: $12000 \mathrm{IU}$ vit.A; $2200 \mathrm{IU}$ vit. D3; $10 \mathrm{mg}$ vit.E; $2.0 \mathrm{mg}$ vit.K3; $1.0 \mathrm{mg}$ vit.B1; $4.0 \mathrm{mg}$ vit.B2; $1.5 \mathrm{mg}$ vit.B6; $0.0010 \mathrm{mg}$ vit.B12; $6.7 \mathrm{mg}$ vit.PP; $6.67 \mathrm{mg}$ vit. B5; $0.07 \mathrm{mg} \mathrm{B8;} 1.67 \mathrm{mg} \mathrm{B9;} 400 \mathrm{mg}$ Choline chloride; $133.4 \mathrm{mg} \mathrm{Mg} ; 25.0 \mathrm{mg} \mathrm{Fe} ; 22.3 \mathrm{mg} \mathrm{Zn;} 10.0 \mathrm{mg} \mathrm{Mn;1.67} \mathrm{mg} \mathrm{Cu;0.25} \mathrm{mg} \mathrm{I} \mathrm{and} 0.033 \mathrm{mg} \mathrm{Se}$

\section{Total lipid extraction and determination}

The Soxhlet extraction procedure is a semi-continuous process, which allows the buildup of the solvent in the extraction chamber for 5 to $20 \mathrm{~min}$. The solvent surrounds the sample and is then siphoned back into the boiling flask. Multi-extractor units are available for extraction of lipids from several different samples or replicate runs of the same material. The procedure provides a soaking effect and does not permit channeling. The fact that polar and bound lipids are not removed is a drawback to the procedure. Extraction was performed using n-hexane $\left(60-80^{\circ} \mathrm{C}\right)$ and $500 \mathrm{ml}$ flat-bottom flask in three replicates for 12 hours.

\section{Determination of fatty acids}

\section{Methylation of fatty acids}

The fatty acids of oil were converted to methyl esters using methyl alcohol. $3 \%$ sulphoric acid in methanol was prepared $\left(3 \mathrm{ml} \mathrm{H}_{2} \mathrm{SO}_{4}+97 \mathrm{ml}\right.$ methanol). Reflexed at $90^{\circ} \mathrm{C}$ for $3 \mathrm{hrs}$ and re-extracted with n-hexane. Leave over night with sodium sulphate. Whole extract was concentrated by rotary evaporator and then Inject into G.C.

\section{Identification and determination of fatty acids by Gas Chromatography (GC)}

Perkin Elmer Auto System XL; equipped with flame ionization detector (FID); fused silica capillary column DB-5 (60 x $0.32 \mathrm{~mm}$ ) was used. Oven temperature was maintained initially at $150^{\circ} \mathrm{C}$ and programmed from 150 to $240^{\circ} \mathrm{C}$ at rate $3^{\circ} \mathrm{C} \cdot \mathrm{min}^{-1}$. Injector temperature $\left(230^{\circ} \mathrm{C}\right)$; detector temperature $\left(250^{\circ} \mathrm{C}\right)$ and helium (carrier gas) flow rate at $1 \mathrm{ml} \cdot \mathrm{min}^{-1}$ were maintained.

\section{Total phenolic, antioxidant}

Total phenolic (Singleton and Rossi, 1965); total reducing power Paget and Barnes, (1964) and total antioxidant activity (Prieto et al., 1999). Furthermore, percentage of the antioxidant activity was evaluated by method described by Brand-Williams et al. (1995) using DPPH (2,2-diphenyl-1-picrylhydrazyl-hydrate) for initiation of the free radicals. Total antioxidant capacity (TAC) of Amphora acetone extract was spectrophotometrically estimated according to method described by Koracevic et al. (2001) at wavelength $505 \mathrm{~nm}$. 


\section{Salim et al.}

\section{Experimental measurements}

\section{Climate changes}

Changes in maximum and minimum ambient air temperatures $\left(\mathrm{AT},{ }^{\circ} \mathrm{C}\right)$ and relative humidity $(\mathrm{RH}, \%)$ were daily recorded inside the rabbitry using electronic digital thermo-hygrometer. Also, the relationship between AT and RH, which termed to temperature-humidity index (THI), was calculated according to the equation of Marai et al. (2002). The equation was as follow;

$\mathrm{THI}=\mathrm{db}{ }^{\circ} \mathrm{C}-\left[(0.31-0.31 \times \mathrm{RH} / 100)\left(\mathrm{db}{ }^{\circ} \mathrm{C}-14.4\right)\right]$, where $\mathrm{db}{ }^{\circ} \mathrm{C}$ represents the dry bulb temperature in degrees Celsius and $\mathrm{RH}$ is the relative humidity expressed as a percentage (Table 2)

The THI values obtained were then classified as follows; (27.8 and less) absence of heat stress, (27.8 28.9) moderate heat stress, $(28.9-30.0)$ severe heat stress and (30.0 and more) very severe heat stress (Marai et al., 2002).

Table (2): Maximum and minimum air temperatures $\left(\mathrm{AT},{ }^{\circ} \mathrm{C}\right)$, and relative humidity $(\mathrm{RH}, \%)$

\begin{tabular}{lll}
\hline Variable & Maximum & Minimum \\
\hline AT $\left({ }^{\circ} \mathrm{C}\right)$ & $35.79 \pm 0.18$ & $27.88 \pm 0.16$ \\
RH $(\%)$ & $71.14 \pm 0.55$ & $28.43 \pm 0.98$ \\
THI (units) & $33.67 \pm 0.15$ & $24.71 \pm 0.12$ \\
\hline
\end{tabular}

Relative humidity $(\mathrm{RH}, \%)$, Calculated values for the temperature-humidity index (THI) inside the rabbitry during the experimental period (Mean $\pm S E$ ).

\section{Productive performance}

Throughout the experimental period, body weight was recorded weekly and average body weight gain was calculated. Feed intake was determined precisely and given as grams per rabbit per week. From each cage, feed residuals were collected daily, weighed and taken into consideration for the calculation of feed intake and feed conversion ratio.

\section{Slaughtering and carcass traits}

At the end of the experimental period (12 weeks), from each group, randomly 6 rabbits were taken, fasted for $12 \mathrm{~h}$, individually weighed and immediately slaughtered. After complete bleeding, pelt, viscera and tail were removed, and then the carcass and its components were weighed as edible parts. The nonedible parts containing lung, liver, spleen, stomach, intestine, and cecum weighed as percentage of preslaughter weight. Dressing percentage was calculated by dividing the hot dressed carcass weight by preslaughter weight and expressed as a percentage.

\section{Blood biochemical parameters}

At the end of experiment, blood samples ( $5 \mathrm{ml}$ from four groups) were randomly collected during slaughter time. Plasma was separated from blood by centrifugation at $3000 \mathrm{rpm}$ for 15 min and stored at $-20^{\circ} \mathrm{C}$ till assayed. Plasma total protein, albumin, total cholesterol and triglycerides were measured calorimetrically using commercial kits (purchased from Bio-diagnostic, Cairo, Egypt) according to the manufacturers' instructions. Total protein was determined according to Orsonneau et al. (1989). Albumin was determined according to the method of Doumas et al. (1971). Plasma globulin concentration was calculated by the difference between total protein and albumin. Triglycerides were determined according to Wahlefeld (1974). Blood plasma malondialdehyde (MDA), Total antioxidant capacity (T-AOC) was determined according to Koracevic et al. (2001) and catalase (CAT) activity was measured according to Aebi (1984).

\section{Statistical analysis}

Data were analyzed by the least square analysis of variance using the General Linear Model Procedure (SAS, 2004). The design was one way analysis and the model was as follows:

$\mathrm{Y}_{\mathrm{ij}}=\mu+\mathrm{Tr}_{\mathrm{i}}+\mathrm{e}_{\mathrm{ij}}$ Where, $\mathrm{Y}_{\mathrm{ij}}=$ any observation of $\mathrm{j}$ th animal within $\mathrm{i}$ th treatment. $\mu=$ overall mean. $\operatorname{Tr}_{\mathrm{i}}=$ effect of $\mathrm{i}^{\text {th }}$ treatment (i: $\left.1-4\right)$. $\mathrm{e}_{\mathrm{ij}}=$ experimental error.

Duncan Multiple Range Test (Duncan, 1955) was used to test the level of significant among means. 


\section{RESULTES AND DISCUSSION}

\section{Chlorophylls and carotenoids}

Growth conditions. This goes back to its growth pattern, where this alga able to complete its life Chlorophyll content of Amphora as well as most of its familiar is very sensitive to the ambient cycle within a wide range of nutrients content and salinity margin. It is closely associated with the carotenoids content, where decreasing of chlorophyll content is accompanied with the rise of carotenoids and oils with a marked decrease in protein content (Table 3 ).

Table (3): Chlorophylls and carotenoids content of three batches outdoor grown A. coffeaeformis

\begin{tabular}{ll}
\hline Pigment & Concentration $\left(\mathrm{mg}^{\mathrm{g}} \mathrm{g}^{-1}\right)$ \\
\hline Total chlorophyll & $28.09 \pm 0.04$ \\
Chlorophyll a & $19.94 \pm 0.06$ \\
Chlorophyll b & $7.71 \pm 0.05$ \\
Total carotenoids & $10.94 \pm 0.04$ \\
\hline
\end{tabular}

\section{Total lipid and fatty acids}

On the average, oil content of Amphora ranged reached about $7.0 \%$ and the differences were found in concern to outdoor growth condition (temperature and harvesting time). In addition, total unsaturated fatty acids reached 75.0 of total fatty acids and its fraction was 21.43 of $\omega 3$ and 12.89 of $\omega 6$-fatty acids. (Table 4).

Table (4): Fatty acids methyl ester profile of $A$. coffeaeformis

\begin{tabular}{lll}
\hline C No. & Fatty acid & $\%$ \\
\hline C14:0 & Myristic acid & 3.33 \\
C14:1 & Myristoleic acid & 1.42 \\
C16:0 & Palmitic acid & 14.27 \\
C16:1 & Palmitoleic acid & 7.88 \\
C18:0 & Stearic acid & 2.19 \\
C18:1 & Oleic acid & 19.26 \\
C18:2 n6 & Linoleic acid & 10.06 \\
C18:3 n & $\gamma$-linolenic acid (GLA) & 1.97 \\
C18:3 n 3 & a-linolenic acid) & 7.69 \\
C20:0 & Arachidonic acid & 4.16 \\
C20:1 & Eicosenoic acid & 3.16 \\
C20:2 & Eicosadienoic acid & 2.78 \\
C20:3 n3 & Eicosatrienoic acid & 3.14 \\
C20:4 & Eicosatetraenoic acid & 6.02 \\
C22:1 & Erucic acid & 1.06 \\
C20:5 n3 & Eicopentanoic acid & 4.19 \\
C22:6 n3 & Docosahexaenoic acid & 6.41 \\
TSFA & & 24.96 \\
TUSFA & & 75.04 \\
\hline
\end{tabular}

\section{Total phenolic}

Phenolic compounds in the acetone extract of A. Coffeaeformis are presented in Table (5). 
Table (5): HPLC analysis of the phenolic in the acetone extract of A.Coffeaeformis

\begin{tabular}{lc}
\hline Compound & Concentration $\left(\mu \mathrm{g}^{-1}\right)$ \\
\hline Gallic acid & 20.19 \\
Protocatechuic acid & 17.63 \\
p-Hydroxybenzoic acid & 6.12 \\
Catechin & 41.17 \\
Chlorogenic acid & 12.56 \\
Caffeic acid & 16.35 \\
p-Coumaric acid & 36.14 \\
Cinamic acid & 14.09 \\
\hline
\end{tabular}

\section{Antioxidant activity}

Table (6): Total polyphenols and antioxidant efficiency of $A$. coffeaeformis acetone extracts against free radicals

\begin{tabular}{lccc}
\hline $\begin{array}{l}\text { Polyphenol } \\
\mathrm{mg} .100 \mathrm{~g}^{-1} \text { gallic }\end{array}$ & $\begin{array}{c}\text { Reducing power } \\
\mu \mathrm{g} . \mathrm{ml}^{-1}\end{array}$ & $\begin{array}{c}\text { Antioxidant capacity mg. } \\
\mathrm{g}^{-1} \text { gallic }\end{array}$ & $\begin{array}{c}\text { Antioxidant } \\
\text { Activity } \%\end{array}$ \\
\hline $0.531 \pm 0.004$ & $8.01 \pm 0.041$ & $85.22 \pm 0.09$ & 87 \\
\hline
\end{tabular}

\section{Productive performance}

The results of the effect of ACE in drinking water on V-line rabbits growth performance under heat stress conditions are presented in Table (7). The results showed that there were no significant differences between groups in final body weight or body weight gain at the age of 12 week. However, group T2 recorded significantly $(\mathrm{P}<0.05)$ the highest feed intake and the worst feed conversion. While, the best feed conversion recorded by $\mathrm{T} 1(1 \mathrm{ml}$ vit.\&min. mix/L drinking water) and $\mathrm{T} 3(1 \mathrm{ml} \mathrm{ACE} / \mathrm{L}$ drinking water) compared to $\mathrm{T} 2$ ( $0.5 \mathrm{ml} \mathrm{ACE} / \mathrm{L}$ drinking water)

The improvement of feed conversion with supplementation A. coffeaeformis, may attribute to the improved intestinal tract conditions and nutrient availability which due to the antimicrobial effects of Amphora (Ayoub et al., 2019). In Addition, A. coffeaeformis contains several nutrients, especially, unsaturated fatty acids that reached 75.0 of total fatty acids and its fraction was 21.43 of $\omega 3$ and 12.89 of $\omega 6$-fatty acids. (Table 4) and that may improve growth. Moreover, through attenuation of oxidative stress, enhancement of antioxidant enzymes activities through high contents of phenolic compounds (Table 5). These results are in agreement with the finding of Abdelnour et al. (2019) who supplemented rabbit diets with Chlorella vulgaris Microalgae. Also, with Peiretti and Meineri (2008), Kim et al. (2010), Seyidoğlu and Galip (2013) and Khanna et al. (2016) who showed that the final weight, weight gain did not differ significantly as a result of supplemented rabbit diets with Spirulina platensis microalgae. Moreover, Ayoub et al. (2019) showed that supplemented Nile tilapia diets with A coffeaeformis diatoms algae with three concentration $(10,20$ and $30 \mathrm{~g} / \mathrm{kg}$ diet) leads to enhance the growth performance, feed efficiency.

Table (7): Productive performance of growing V-line rabbits drinking water supplemented with ACE.

\begin{tabular}{|c|c|c|c|c|c|}
\hline \multirow{2}{*}{ Trait } & \multicolumn{4}{|c|}{ Treatment } & \multirow{2}{*}{ SEM } \\
\hline & $\mathrm{C}$ & $\mathrm{T} 1$ & $\mathrm{~T} 2$ & T3 & \\
\hline Initial body weight (IBW, g) & 852.5 & 861.9 & 849.2 & 849.6 & 47.5 \\
\hline Final body weight (FBW, g) & 1740.8 & 1815.7 & 1692.3 & 1777.8 & 51.1 \\
\hline Total body gain (TBG, g) & 888.3 & 953.8 & 843.1 & 928.2 & 39.8 \\
\hline Total feed intake (TFI, g) & $3615.1^{\mathrm{ab}}$ & $3475.3^{\mathrm{b}}$ & $3672.9^{\mathrm{a}}$ & $3500.1^{\mathrm{ab}}$ & 60.8 \\
\hline Feed conversion ratio (FCR) & $4.17^{\mathrm{ab}}$ & $3.69^{\mathrm{b}}$ & $4.55^{\mathrm{a}}$ & $3.81^{\mathrm{b}}$ & 0.21 \\
\hline
\end{tabular}




\section{Carcass traits}

The results of carcass traits that shown in Table (8) shows that supplementation of rabbit diets with ACE at the level of 0.5 or $1 \mathrm{ml} / 1$ drinking water had no impact on the percentage of internal organs (kidney, liver, heart, spleen, lung, stomach and ceacum) or ceacum length. However, T1 group recorded significantly $(\mathrm{p}<0.05)$ the highest dressing percentage compared to T2 group. This results are in agreement with Abdelnour et al. (2019) who indicated that supplemented the rabbit diets with Chlorella vulgaris microalgae did not induce significant differences $(\mathrm{p}>0.05)$ in carcass traits (dressing percentage, giblets, heart, kidney, lung, and liver) as compared to the control animals. However, Kim et al. (2010) After 8 weeks of treatment rabbits with 1 or 5\% Spirulina platensis microalgae, organ weights were not significantly different in spleen, kidney, and heart among the groups. Moreover, Spirulina microalgae addition did not significantly influence the carcass yield or the proportions of the various carcass parts and organs (Peiretti and Meineri, 2011).

Table (8): Carcass traits of growing V-line rabbits supplemented with ACE in drinking water.

\begin{tabular}{lccccc}
\hline \multirow{2}{*}{ Trait } & \multicolumn{3}{c}{ Treatment } & \multirow{2}{*}{ SEM } \\
\cline { 2 - 5 } & $\mathrm{C}$ & $\mathrm{T} 1$ & $\mathrm{~T} 2$ & $\mathrm{~T} 3$ & \\
\hline Pre-slaughter weight (g) & 1687.5 & 1718.3 & 1759.2 & 1759.2 & 55.33 \\
Dressed weight (g) & 1065.0 & 1100.8 & 1065.0 & 1092.5 & 41.36 \\
Empty carcass (g) & 983.3 & 991.7 & 972.5 & 1016.7 & 42.76 \\
Dressing \% & $63.1^{\mathrm{ab}}$ & $64.1^{\mathrm{a}}$ & $60.4^{\mathrm{b}}$ & $62.0^{\mathrm{ab}}$ & 0.95 \\
Kidney \% & 0.74 & 0.79 & 0.80 & 0.76 & 0.04 \\
Liver \% & 2.8 & 2.8 & 2.9 & 3.0 & 0.18 \\
Heart \% & 0.31 & 0.31 & 0.30 & 0.32 & 0.02 \\
Spleen \% & 0.05 & 0.05 & 0.05 & 0.05 & 0.01 \\
Lung \% & 1.05 & 0.95 & 0.88 & 0.81 & 0.12 \\
Stomach \% & 5.7 & 5.5 & 5.7 & 5.1 & 0.29 \\
Ceacum \% & 4.8 & 4.9 & 7.0 & 5.6 & 0.71 \\
Ceacum length (cm) & 45.0 & 44.3 & 45.7 & 45.4 & 1.49 \\
\hline
\end{tabular}

${ }^{a, b}$ Means bearing different superscripts within the same row are significantly different $(P<0.05)$.

Control = rabbits drank water without additives, $T 1=$ rabbits drank water supplemented with vitamins and minerals, $T 2=$ rabbits drank water supplemented with $0.5 \mathrm{ml}$ ACE, T3 = rabbits drank water supplemented with $1 \mathrm{ml}$ ACE.

\section{Blood biochemical components}

\section{Blood hematological}

The results of blood hematology are presented in Table (9). There were no significant different among groups in Hematocrit, Total leucocytes count, Lymphocytes and Neutrophils percentage, while T3 (1 ml ACE/L drinking water) group recorded significantly $(\mathrm{p}<0.05)$ the highest values of Hemoglobin and Red blood cells count (10.73 and $5.45^{*} 10^{6}$ respectively) compared to control ( 9.07 and $4.33^{*} 10^{6}$ respectively). These results are in contrast with the finding of Abdelnour et al. (2019) who indicated that dietary Chlorella vulgaris Microalgae supplementation had a significant effect $(\mathrm{p}<0.05)$ in the all blood hematology traits were detected except for hemoglobin and red blood cells count. El-Ratel (2017) indicated that treatment of does with Spirulina platensis significantly $(\mathrm{P}<0.05)$ increased hemoglobin $\mathrm{Hb})$ concentration, count of red blood cells (RBCs) and hematocrit value (Ht). in the current study improving of $\mathrm{Hb}$ and $\mathrm{RBCs}(\mathrm{p}<0.05)$ in A coffeaeformis group T3 might be due to the strong antioxidant effect of on hematopoietic cells, which appears to be particularly vulnerable in the presence of unchecked accumulation of reactive oxygen species, ROS (Kong et al., 2004). Also, high content of USFs and omega3 fatty acid of A. coffeaeformis extract (Table 4). El-Moghazy et al. (2014) showed that feeding diet supplemented with omega-3 were significantly increased the percentages of hemoglobin, platelets and the mean corpuscular hemoglobin.

\section{Blood metabolites}

Results of Blood metabolites are shown in Table (10). Supplementation of ACE to growing rabbit drinking water insignificantly affected on the total protein, albumin, globulin, total cholesterol, triglycerides, alanine aminotransferase (GPT), uric acid and creatinine. While, T1 (vit. and min. group) recorded significantly $(\mathrm{p}<0.05)$ the highest value of Aspartate aminotransferase $(\mathrm{GOT})$ compared to 


\section{Salim et al.}

control group. These results are in agreement with Abdelnour et al. (2019) who showed that most of the serum parameters were non-significantly different by Chlorella vulgaris microalgae supplementation in rabbit diets. Also, Seyidoğlu and Galip (2014) and Khanna et al. (2016) who indicated that there were no significant changes in serum biochemical indices as a result of supplemented rabbit diets with Spirulina platensis. While there were significant decreased in triglycerides, total cholesterol and activity AST and ALT in blood plasma in Spirulina platensis microalgae groups compared to control (El-Ratel, 2017). Moreover, Ayoub et al. (2019) showed that serum ALT and AST were within normal values in all treatment groups treated with A. coffeaeformis microalgae compared the control group of Nile tilapia fish.

Table (9): Blood hematological of growing V-line rabbits drinking water supplemented with ACE.

\begin{tabular}{|c|c|c|c|c|c|}
\hline \multirow{2}{*}{ Parameters } & \multicolumn{4}{|c|}{ Treatments } & \multirow{2}{*}{ SEM } \\
\hline & $\mathrm{C}$ & T1 & $\mathrm{T} 2$ & T3 & \\
\hline Hemoglobin $(\mathrm{Hb})$ & $9.07^{\mathrm{b}}$ & $10.4^{\mathrm{ab}}$ & $9.22^{\mathrm{b}}$ & $10.73^{\mathrm{a}}$ & 0.39 \\
\hline Hematocrite (Ht) & 31.23 & 36.5 & 31.7 & 36.5 & 1.53 \\
\hline Red blood cells (RBCs)*10 $10^{6}$ & $4.33^{\mathrm{c}}$ & $5.23^{\mathrm{ab}}$ & $4.62^{\mathrm{bc}}$ & $5.45^{\mathrm{a}}$ & 0.22 \\
\hline Total leucocytes & 6600 & 7266 & 6725 & 7566 & 980 \\
\hline Lymphocytes & 40.0 & 47.0 & 44.5 & 37.33 & 4.45 \\
\hline Neutrophils & 50.33 & 40.0 & 45.75 & 50.33 & 5.17 \\
\hline
\end{tabular}

Table (10): Blood metabolites of growing V-line rabbits drank water supplemented with ACE.

\begin{tabular}{llllll}
\hline \multirow{2}{*}{ Parameter } & \multicolumn{2}{l}{ Treatment } & \multicolumn{3}{c}{ SEM } \\
\cline { 2 - 5 } & $\mathrm{C}$ & $\mathrm{T} 1$ & $\mathrm{~T} 2$ & $\mathrm{~T} 3$ & \\
\hline Total protein mg/dl & 6.02 & 6.13 & 6.31 & 6.10 & 0.47 \\
Albumin mg/dl & 3.58 & 3.68 & 3.67 & 3.54 & 0.25 \\
Globulin mg/dl & 2.44 & 2.45 & 2.64 & 2.57 & 0.23 \\
Total cholesterol mg/dl & 196.67 & 186.15 & 195.75 & 198.83 & 11.81 \\
Triglycerides mg/dl & 132.10 & 129.22 & 130.66 & 133.69 & 8.55 \\
ALT U/l & 62.15 & 68.37 & 63.90 & 68.11 & 3.47 \\
AST U/l & $64.28^{\mathbf{b}}$ & $81.98^{\mathbf{a}}$ & $65.37^{\mathbf{b}}$ & $74.79^{\text {ab }}$ & 4.63 \\
Uric acid mg/dl & 5.55 & 5.46 & 5.46 & 5.60 & 0.38 \\
Creatinine mg/dl & 0.90 & 0.86 & 0.88 & 0.92 & 0.11 \\
\hline
\end{tabular}

${ }^{a, b}$ Means bearing different superscripts within the same row are significantly different $(P<0.05)$. Control $=$ rabbits drank water without additives, $T 1=$ rabbits drank water supplemented with vitamins and minerals, $T 2=$ rabbits drank water supplemented with $0.5 \mathrm{ml}$ ACE, T3 = rabbits drank water supplemented with $1 \mathrm{ml}$ ACE.

\section{Blood antioxidant activity}

The effect of ACE on blood antioxidant activity of rabbits under heat stress conditions are summarized in Table (11). All supplemented groups had significantly $(\mathrm{p}<0.05)$ less values of TAOC compared to control. While A. coffeaeformis extract recorded significantly $(\mathrm{p}<0.05)$ better values of malondialdehyde (MDA) and catalase activity compared to control and T1. In present study decreasing of plasma MDA as a result of supplementation rabbit drinking water with ACE is an index of lipid peroxidation and oxidative stress decreasing (Safari et al., 2018). Also, the higher $(\mathrm{P}<0.05)$ activity of catalase enzyme (192.15, 212.80 and 249.30 in T1 T2 and T3 respectively) considered as indication increasing cellular defense against oxygen free radicals and oxidative stress (Bernabucci et al., 2002). It could be concluded that $A$. coffeaeformis algae extract enhanced the antioxidative status of rabbits by minimizing lipid peroxidation and increase the activity of catalase.

These results are in agreement with Abdelnour et al. (2019) who showed that supplementing growing rabbit diets with Chlorella vulgaris microalgae reduced the serum levels of malondialdehyde (MDA) compared to the control. While, No significant changes were detected in the activities of TAC compared to control. Also, El-Ratel and Gabr (2019) showed that Spirulina platensis supplementation group had significantly $(\mathrm{p}<0.05)$ better, antioxidant capacity (total antioxidant capacity, glutathione, malondialdehyde and catalase) in heat stressed rabbits. Also, El-Ratel 2017 indicated that total 
antioxidant capacity $(\mathrm{TAC})$ increased significantly $(\mathrm{P}<0.05)$ in blood plasma of doe rabbits administrated with Spirulina Alga. In addition, Kim et al. (2010) showed that Oxidative stress biomarkers were significantly improved in the liver and red blood cells of rabbits fed Spirulina platensis. Moreover, Mobarez et al. (2018) indicated that supplementing laying hen diets with $3 \mathrm{~g} \mathrm{SP} / \mathrm{kg}$ diet resulted in a significant increase $(\mathrm{P} \leq 0.01)$ in TAOC compared to the control group. In Addition, El-Sayed (2018) indicated that acetone extract of $A$. coffeaeformis alga exhibited the highest scavenging activity against attack of free radicals generated as a result of oxidative stress and induced by paracetamol in liver tissues in rats.

Table (11): Blood antioxidant activity of growing V-line rabbits drinking water supplemented with ACE.

\begin{tabular}{lccccc}
\hline \multirow{2}{*}{ Parameter } & \multicolumn{4}{c}{ Treatment } & \multirow{2}{*}{ SEM } \\
\cline { 2 - 4 } TAOC (mmol/l) & $\mathrm{C}$ & $\mathrm{T} 1$ & $\mathrm{~T} 2$ & $\mathrm{~T} 3$ & \\
Catalase (U/g) & $1.14^{\mathrm{a}}$ & $0.84^{\mathrm{b}}$ & $0.77^{\mathrm{b}}$ & $0.67^{\mathrm{b}}$ & 0.06 \\
MDA (mmol/l) & $152.90^{\mathrm{c}}$ & $192.15^{\mathrm{b}}$ & $212.80^{\mathrm{b}}$ & $249.30^{\mathrm{a}}$ & 9.84 \\
\hline
\end{tabular}

$\overline{a, b, c}$ Means bearing different superscripts within the same row are significantly different $(P<0.05)$.

Control $=$ rabbits drank water without additives, $T 1=$ rabbits drank water supplemented with vitamins and minerals, $T 2=$ rabbits drank water supplemented with $0.5 \mathrm{ml}$ ACE, T3 = rabbits drank water supplemented with $1 \mathrm{ml}$ ACE.

\section{CONCLUSION}

It can be concluded that the present study demonstrated that A. coffeaeformis alga extract have the potential to be used as a sources of natural antioxidant and nutrients for growing rabbits without causing any adverse effects on growth or physiological functions, and the best dose in drinking water is $1 \mathrm{ml} / \mathrm{L}$. Moreover, there are not enough studies about the effects of diatoms on animals. So, we need more researches about that.

\section{REFERENCES}

Abdelnour, S.A.; A.M. Sheiha; A.E. Taha; A.A. Swelum; S. Alarifi; S. Alkahtani; D. Ali; G. AlBasher; R. Almeer; F. Falodah; B. Almutairi; M.M. Abdel-Daim; M.E. Abd El-Hack and I.E. Ismail (2019) Impacts of Enriching Growing Rabbit Diets with Chlorella vulgaris Microalgae on Growth, Blood Variables, Carcass Traits, Immunological and Antioxidant Indices. Animals 9, 788; doi:10.3390/ani9100788

Aebi, H. (1984) Catalase in vitro. Mthods in enzymol. 105: 121-126

Agriculture Ministry Decree (1996). The standard properties for ingredients, Feed additives and manufactured for animal and poultry. El Wakaee El-Masria , No. 192 (1997) P 95 Amirria press Cairo, Egypt.

Alhidary, I.; S. Shini; R. Al Jassim and J. Gaughan (2012). Effect of various doses of injected selenium on performance and physiological responses of sheep to heat load. J AnimSci 90:2988-2994

Ayoub, H.F.; M.F. Abdelghany and A.B. El-Sayed (2019) Effects of Diatoms Amphora coffeaeformis on growth parameters, nonspecific immunity and protection of the Nile tilapia (Oreochromis niloticus) to Aeromonas hydrophila infection. Egyptian Journal of Aquatic Biology \& Fisheries Vol. 23(1): 413 426.

Badr, M.A.; Nibal A. Hassan; T.A. Ghattas, and A.B. El-Sayed (2017). Effects of amphora coffeaeformis algae extract on morphology and antioxidant enzymes of cryopreserved buffalo spermatozoa. J. Egypt. Vet. Med. Assoc.; 77, 3. $607-618$.

Banerjee, S; W.E. Hew; H. Khatoon; M. Shariff and F.M. Yusoff (2011) Growth and proximate composition of tropical marine Chaetoceros calcitrans and Nannochloropsis oculata cultured outdoors and under laboratory conditions. Afr J Biotechnol 2011; 10: 1375-83. 


\section{Salim et al.}

Bernabucci, U.; B. Ronchi; N. Lacetera and A. Nardone (2002) Markers of oxidative status in plasma and erythrocytes of transition dairy cows during hot season. Journal of Dairy Science 85, 2173-2179.

Brand-Williams, W.; M.E. Cuvelier; and C. Berset (1995) Use of a free radical method to evaluate antioxidant activity. Lebenson Wiss Technol 28(1):25-30

Brown, E.S.; P. J. Allsopp; P.J. Magee; C.I.R. Gill; S. Nitecki; C. R. Strain and E.M. McSorley (2014). Seaweed and human health. Nutr. Rev. 72, 205-216.

Davies, B.H. (1976) Carotenoids. In: Goodwin TW (ed) Chemistry and biochemistry of plant pigments. Academic Press, London, pp 38-165

Doumas, B. T.; W.A Watson and H.G. Biggs (1971) Albumin standers and measurements of albumin with bromocresol green. Clin. Chim. Acta, 31; 87-89

Duncan, D.B., 1955. Multiple range and Multiple F test. Biometrics, 11: 1-42.

El-Moghazya, M.; N. S. Zedan ; A. M. El Atrash; M.El-Gogary and E. Toussonce (2014) The possible effect of diets containing fish oil (omega-3) on hematological, biochemical and histopathogical alterations of rabbit liver and kidneyBiomedicine \& Preventive Nutrition 4, (3) 371-377

El-Ratel, I.T. (2017) Reproductive Performance, Oxidative Status And Blood Metabolites Of Doe Rabbits Administrated With Spirulina Alga. Egypt. Poult. Sci. Vol 37(IV) 1153-1172

El-Ratel, I.T. and A.A. Gabr (2019) Effect of Spirulina and Vitamin E on Reproduction and in vitro Embryo Production in Heat-stressed Rabbits. Pak. J. Biol. Sci., 22 (11): 545-553.

El-Sayed A.B.; S.A. Shehata; Sahar Taha; H.A. Hamouda and D.M. Youssef (2018 a). Algae extract overcoming the adverse effects of saline stress of hydroponic tomato grown plants. Journal of Food, Agriculture \& Environment. 16(2), 92-99.

El-Sayed, A.B.; F.E. Abdalla and A.A. Abdel-Maguid (2001) Use of some commercial fertilizer compounds for Scenedesmus cultivation.

El-Sayed, A.B.; W.M. Aboulthanaa; Amal M. El-Feky; M.M. Seif and Noha E. Ibrahim (2018 b). Bio and phyto-chemical effect of Amphora coffeaeformis extract against hepatic injury stress induced by Paracetamol in rats

Enwereuzoh, U.O. and G.N. Onyeagoro (2014) A novel aeration method for the Preparation of algae (Dunaliella Salina) biomass for biofuel production. Am J Eng Res 3(9):209-214

Ganaie, A.H.; G. Shanker; N.A. Bumla; R.S. Ghasura and N.A. Mir (2013). Biochemical and physiological changes during thermal stress in bovines. J VeterinarSciTechnol 4:12

Gillard, P.R.L and J.H. Ryther (1962) Studies on marine planktonic diatom. I. Cyclotella hustedt and Detonula confervaceae (CLEVE) Gran. Can J Microbiol 8:229-239

Habeeb, A. A. M.; A.E. Gad; A. A. EL-Tarabany and M.A.A. Atta (2018). Negative Effects of Heat Stress on Growth and Milk Production of Farm Animals Journal of Animal Husbandry and Dairy Science Volume 2, Issue 1, PP 1-12

Habeeb, A.A.M.; E.S.H. El-Gohary; H.M. Saleh and A.I. Abolnaga, (2008). Effect of summer heat stress conditions and feeding protein level on blood components in Ossimi ewes and their suckling lambs. Egyptian Journal of Applied Science, 23 (6B), 388-408.

Hassan, S. Y.; Zahrat El-Ola, Nadra; M. Mohamed and A.B. El- Sayed (2015). Production and Evaluation of Pasta Supplemented with Spirulina platensis Biomass. Advances in Food Sciences. 37(4).153-162.

Khanna, S.; H.K. Gulati; S. Kumar and P.K. Kapoor (2016) Effect of Emblica officianalis and Spirulina platensis on growth performance and serum biochemical parameters in rabbits. Indian J. Anim. Res., $50(6)$ : $915-918$

Khatoon, H.: S. Banerjee; F.M. Yusoff and M. Shariff (2009) Evaluation of indigenous marine periphytic Amphora, Navicula and Cymbella grown on substrate as feed supplement in Penaeus monodon postlarval hatchery system. Aquaculture Nutrition 15. (2) 186-193.

Kim, M.Y.; S.H. Cheong; J.H. Lee; M. J. Kim; D.E. Sok and M.R. Kim (2010) Spirulina Improves Antioxidant Status by Reducing Oxidative Stress in Rabbits Fed a High-Cholesterol Diet. J Med Food 13 (2) 420-426 
Kong, Y. I.; S. Zhou; A.J. Kihm; A.M. Katein and X. Yu (2004) Loss of hemoglobin-stabilizing protein impairs erythropoiesis and exacerbates \$-thalassemia. J. Clin. Invest., 114: 1457-1466

Koracevic, D.; G. Koracevic; V. Djordjevic; S. Andrejevic and V. Cosic (2001) Method for the measurement of antioxidant activity in human fluids. J Clin Pathol 154(5):356-361

Lee, S. H.; R. Karawita; A. A. Rohan; J. B. Lee; K. W. Lee; B. J. Lee; D. W. Kim and Y.J. Jeon (2009). Potential of Benthic Diatoms Achnantheslongipes, Amphora coffeaeformisandNavicula sp. (Bacillariophyceae) as Antioxidant Sources ALGAE 24, Issue 1, pp.47-55

Lee, S.H.; , R. Karawita; Abu affan; J.B. Lee; B.J. Lee; and Y.J. Jeon (2008) Potential Antioxidant Activites of Enzymatic Digests from Benthic Diatoms Achnanthes longipes, Amphora coffeaeformis, and Navicula sp. (Bacillariophyceae) J Food Sci Nutr. 13, 166-175.

Leflaive, J. and L. Ten-Hage (2009). Chemical interactions in diatoms: role of polyunsaturated aldehydes and precursors. New Phytol.184, 794-805.

Marai, I.F.M.; A.A.M. Habeeb and A.E. Gad (2002). Reproductive traits of male rabbits as affected by climatic conditions, in the subtropical environment of Egypt. Animal Science, 75, 451-458

Marai, I.F.M.; A.A.M. Habeb and A.E. Gad (2008). Performance of New Zealand White and Californian male weaned rabbits in the subtropical environment of Egypt. AnimSci J 79(4):472-480

McKee, J.S. and P.C. Harrison (2013). Supplemental ascorbic acid does not affect inferred heat loss in broiler chickens exposed to elevated temperature. J Therm Biol 38:159-162

Mobarez, S.M.; A.M. Rizk; A.M. Abdel latif and O.A. El-Sayed (2018) Effect Of Supplementing Diet With Spirulina Platensis Algae Or Turmeric On Productive And Reproductive Performance Of Golden Montazah Layers. Egypt.Poult. Sci.Vol 38 (I) 109-125

Molina-Cárdenas, C.A. and M.D.P. Sánchez-Saavedra (2017). Inhibitory effect of benthic diatom species on three aquaculture pathogenic vibrios Algal Research 27 (2017) 131-139

Morera, P.; L. Basiricò; K. Hosoda and U. Bernabucci (2012). Chronic heat stress up-regulates leptin and adiponectin secretion and expression and improves leptin, adiponectin and insulin sensitivity in mice. J MolEndocrinol 48(2):129-138

Mustapha, Y. and S.R. Babura (2009) Determination of carbohydrate and $\beta$-carotene content of some vegetables consumed in Kano Metropolis, Nigeria. Bayero J Pure Appl Sci 2(1):119-121

Nisar, N.A.; M. Sultana; H.A. Waiz; P.A. Para and S.A. Dar (2013). Oxidative stress threat to animal health and production. Int J Livest Res 3:76-83.

Orsonneau, J.L.; P. Douet; C. Massoubre; P. Lustenberger and S. Bernard (1989) An improved pyrogallol red-molybdate method for determining total urinary protein. Clin Chem. 35:2233-2236

Paget, G.E. and J.M. Barnes (1964) Toxicity tests. In: Laurance DR, Bacharach AL (eds) Evaluation of drug activities: pharmacometrics, vol 1. Academic Press, New York, pp 135-165

Peiretti, P.G. and B. Meineri (2008) Effects of diets with increasing levels of Spirulina platensis on the performance and apparent digestibility in growing rabbits. Livestock Science, 118. P 173-177

Peiretti, P.G. and G. Meineri (2011) Effects of diets with increasing levels of Spirulina platensis on the carcass characteristics, meat quality and fatty acid composition of growing rabbits. Livestock Science 140 (2011) 218-224

Prieto, P.; M. Pineda and M. Anguilar (1999) Spectrophotometric quantitation of antioxidant capacity through the formation of a phosphomolybdenum complex: specific application to the determination of Vitamin E. Anal Biochem 269(2): 337-341

Qasem, W.M.A.; E.A. Mohamed; A.A. Hamed; A.B. El-Sayed and R.A. Salah El Din (2016). Antimicrobial and Anticancer Activity of Some Microalgae species. Egyptian J. of Phycol. 17, 33-49.

Rousseaux, C. and W. Gregg (2014). Interannual variation in phytoplankton primary production at a global scale.Remote Sens. 6, 1-19.

Safari A.R.; F. Shariatmadari; M. Sharafi; M.A. Karimi Torshizi and A. Shahverdi (2018) Improvements in semen quality, sperm fatty acids, and reproductive performance in aged Ross breeder roosters fed a diet supplemented with a moderate ratio of n-3: n-6 fatty acids. Poult. Sci. 97 (11), 4113-4121 doi:10.3382/ps/pey278 


\section{Salim et al.}

SAS. 2004. SAS Institute Inc. SAS User's Guide, Statistics. Cary, NC

Seyidoğlu, N. and N. Galip (2014) Effects of Saccharomyces cerevisiae and Spirulina platensis on Growth Performances and Biochemical Parameters in Rabbits. Kafkas Üniversitesi Veteriner Fakültesi Dergisi 20 (3): 331-336. DOI: 10.9775/kvfd.2013.9988

Singleton, V.L. and A.J. Rossi (1965) Colorimetry of total phenolics with phosphomolybdic phosphotungstic acid reagents. Am J Enol. Vitic 16(3):144-158

Tawfeek, S. S.; K. Hassanin and I.M.I. Youssef (2014). The effect of dietary supplementation of some antioxidants on performance, oxidative stress, and blood parameters in broilers under natural summer conditions. J WorldsPoult Res 4(1):10-19

Wahlefeld, A.W. (1974) Triglycerides Determination after Enzymatic Hydrolysis. Methods of Enzymatic Analysis. 4: 1831-1835

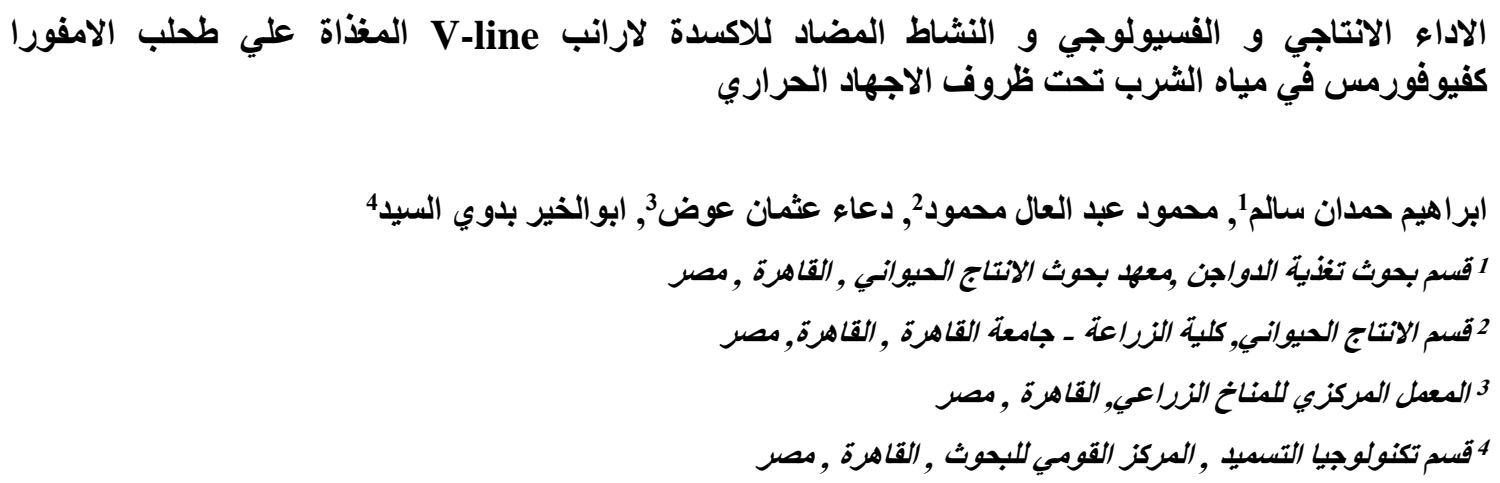

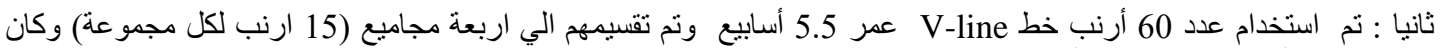

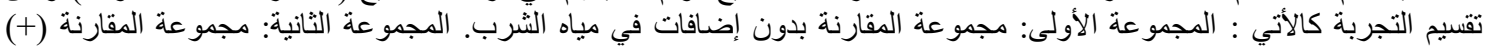

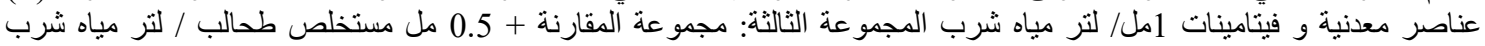

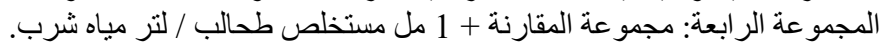

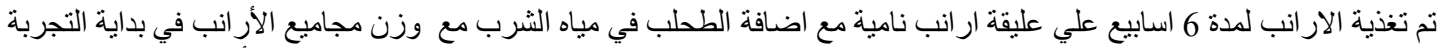

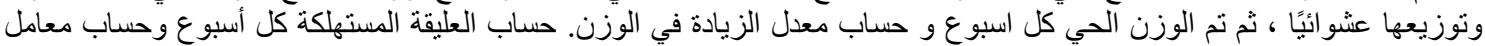

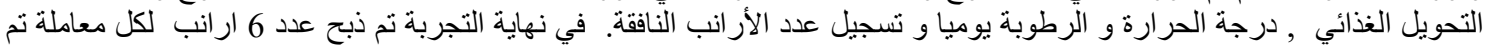

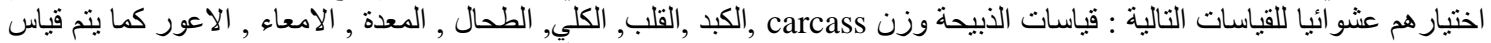

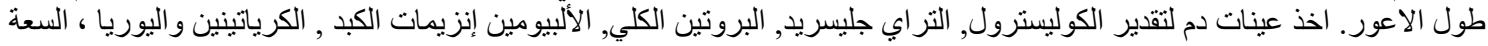

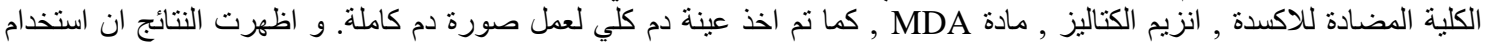

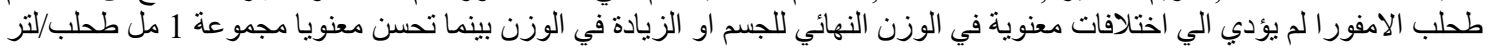

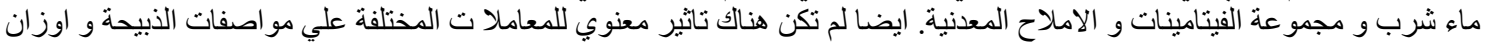

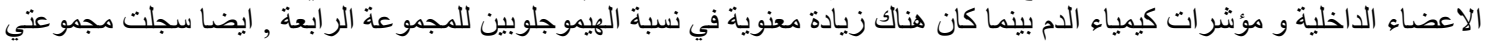

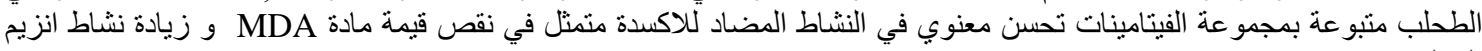

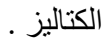

نستنتج من تللك الار اسة انه في حالة الاجهاد الحر اري او التاكسدي او الاجهاد الناتج عن عو امل اخري يمكن استخدام طحلب الامفورا

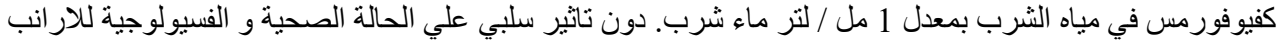

